\title{
EFFICIENCY ANALYSIS OF PRODUCTION FACTORS OF WETLAND PADDY FARMING IN WEST ACEH REGENCY
}

\author{
Fitri Cut Ida*, Mustafa, Azhar \\ Syiah Kuala University, Indonesia \\ *E-mail: cutidaf@gmail.com
}

\begin{abstract}
Appropriate and efficient production management is able to maximize yield continuously in rice farming. Efficiency of production factor one of the effort to increase the ability in farming management especially the use of production factor gives opportunity to increase income for rice commodity. The purpose of this study is to determine the level of efficiency of production factors allocated for wet land paddy farming in West Aceh regency from the economic aspect as well as the amount of income received by rice farmers in the research area. The analysis model used is Cobb Douglas Production Function Analysis, where the result of efficiency analysis found that seed factor, compost fertilizer, and NPK fertilizer are inefficient, while Urea, Pesticide and labor are not efficient yet.
\end{abstract}

\section{KEY WORDS}

Production function, management, wetland rice farming, efficiency, income, West Aceh.

Rice is the most important crop and continues to be cultivated intensively by farmers. This, rice is a staple crop so the availability of rice affects food security, which ensures the availability of food for all people throughout the year on a sustainable basis. Appropriate and efficient production management is able to maximize yield continuously in rice farming.

Farmers in their farms are not only interested in increasing their production, but able to increase income which in turn also increases the benefits for rice farmers. Efforts to increase productivity by using the means of agricultural production, which initially gives a positive effect that is the increase in productivity, but over time decreased productivity and the impact on increasing pest and weeds due to the increasing resistance to pesticides provided by farmers.

The efforts to increase the productivity level of agricultural products have many ways done by the government both directly with integrated agricultural programs and indirectly through research institutions from both universities and independent institutions. In the implementation not all things planned to run, this condition is seen in the field which in the ratio of planning with the results obtained is much different. This difference is in addition to technical aspects of implementation and also due to non-technical factors such as socioeconomic community.

Production development conditions in Kaway XVI Subdistirct and Woyla Subdistrict, which in 2014 the production reached $12,916.00$ tons in the Kaway XVI and 10,121.00 tons in the Woyla, while in 2015 in the Kaway XVI Subdistrict increased to 36,322.07 tons and Woyla Subdistrict increased to 22,797.00 tons, while in 2016 decreased in production so that the Kaway XVI subdistrict became $29,353.80$ tons as well as the sub-district of Woyla dropped to $19,722.00$ tons. This condition illustrates that the fluctuations in the production of lowland rice planted by farmers, the conditions caused are still many farmers have not been able to use production facilities both in terms of quality and quantity which is affect the amount of production.

\section{METHODS OF RESEARCH}

The research location in West Aceh regency was deliberately chosen based on the consideration which Aceh Barat regency was the central of paddy farming in Aceh Province. The location of research conducted in the Kaway XIV subdistirct and Woyla subdistrict. 
The sampling method was a Stratified Random Sampling which was samples grouping into a more homogeneous group.

The population size in this research was 1,587 people, which was divided into 4 Villages in each Subistrict namely Kaway XIV Subdistrict and Woyla Subdistrict. The total population of Kaway XIV Subdistrict reached 730 people with the total sample reached 73 people or $10 \%$ of the total population. While for Woyla subdistrict, the total population reached 857 people with the total sample reached 86 people or $10 \%$ of the total population.

The analysis tool used in this research is Cobb-Douglas Production Function. The equation can be written as follows:

$$
\log Y=\log a+\beta_{1} \log x_{1}+\beta_{2} \log x_{2}+\beta_{3} \log x_{3}+\beta_{4} \log x_{4}+\beta_{5} \log x_{5}+e
$$

Where: $Y=$ Paddy production $(\mathrm{kg} / \mathrm{ha} / \mathrm{mt}) ; X_{1}=$ land area $(\mathrm{ha} / \mathrm{mt}) ; X_{2}=$ seed $(\mathrm{kg} / \mathrm{mt})$; $\mathrm{X}_{3}=$ fertilizer $(\mathrm{kg} / \mathrm{mt}) ; X_{4}=$ pesticide (liter/mt); $X_{5}=$ labor $(\mathrm{HKP} / \mathrm{mt})$.

Calculating the level of production input efficiency in wetland paddy farming in West Aceh regency, the economic efficiency condition requires NPM to be equal to the factor production price:

$$
\frac{a . Y \cdot P_{y}}{X}=P_{x}
$$

Farmers profit is net income of farmers after deducted by production cost and investment cost. According to Suratiyah (2009) the formula for calculating profits as follows:

$$
\mathrm{TR}=\mathrm{Py} . \mathrm{Y}
$$

The calculation of $\mathrm{R} / \mathrm{C}$ can be written as follows:

$$
\mathrm{R} / \mathrm{C}=\frac{\text { Total Revenue }}{\text { Total Cost }}=\frac{Y x P y}{T C}
$$

\section{RESULTS AND DISCUSSION}

The efforts to increase yields on farms is to increase the use of production facilities that will increase the income of local farmers. The magnitude of the factors production influence on paddy production in the analysis by using Cobb Douglass function that has been transformed into the regression equation in the logarithm so that the following results are obtained:

Table 1 - Cobb Douglas Analysis Results on Seed Factors, Compost Fertilizers, NPK Fertilizers, Urea Fertilizers, Pesticides and Labor in Research Areas, 2018

\begin{tabular}{lllll}
\hline Variable & Regression Coefficient & $\mathrm{T}(\mathrm{DF}=158)$ & Prob & $\mathrm{T}_{\text {table }}$ \\
\hline Constants & 1,953 & 4,631 & 0,000 & $0,05=2,44$ \\
$\mathrm{X}_{1}$ & $-0,098$ & $-2,925$ & 0,004 & \\
$\mathrm{X}_{2}$ & -0.008 & $-0,133$ & 0,894 & \\
$\mathrm{X}_{3}$ & $-0,288$ & $-2,800$ & 0,006 & \\
$\mathrm{X}_{4}$ & 1,073 & 6,609 & 0,000 & \\
$\mathrm{X}_{5}$ & 0,101 & 4,119 & 0,000 & \\
$\mathrm{X}_{6}$ & 0,502 & 5,453 & 0,000 & \\
\hline $\mathrm{R}^{2}$ & 0,867 & & $\mathrm{~F}$ Table & $0,05=2,88$ \\
F search & 172,650 & & & \\
\hline
\end{tabular}

Source: Data Primer (diolah), 2018.

$$
\begin{gathered}
\operatorname{Ln} Y=\operatorname{Ln} 1,953+\operatorname{Ln}-0,098 X_{1}+\operatorname{Ln}-0,008 X_{2}+\operatorname{Ln}-0,288 X_{3}+\operatorname{Ln} 1,073 X_{4}+\operatorname{Ln} 0,101 X_{5}+\operatorname{Ln} 0,502 X_{6} \\
Y=7,050+0,907 X_{1}+0,992 X_{2}+0,750 X_{3}+2,924 X_{4}+1,106 X_{5}+1,652 X_{6}
\end{gathered}
$$


The above calculation results show that each addition of seed $\left(X_{1}\right)$ of $1 \mathrm{Kg}$ will cause a production increase of $0.907 \mathrm{Kg} / \mathrm{Ha}$ if the factors $\left(\mathrm{X}_{2}, \mathrm{X}_{3}, \mathrm{X}_{4}, \mathrm{X}_{5}\right.$, and $\left.\mathrm{X}_{6}\right)$ was considered fixed, the hypothesis accepted $\mathrm{Ha}$ and rejected $\mathrm{Ho}$. For seed variables $\left(\mathrm{X}_{1}\right)$ obtained $\mathrm{t}_{\text {find }}=-$ 2.925 , while $t_{\text {table }(\alpha=0,05)}=2.44$. Then $t_{\text {find }}>t$ table which means the null hypothesis is rejected and the alternative hypothesis is accepted at $95 \%$ level.

Each addition of compost $\left(X_{2}\right)$ of $1 \mathrm{Kg}$ will result in increased production of $0.992 \mathrm{Kg} /$ $\mathrm{Ha}$ if the production factors $\left(\mathrm{X}_{1}, \mathrm{X}_{3}, \mathrm{X}_{4}, \mathrm{X}_{5}\right.$, and $\left.\mathrm{X}_{6}\right)$ are considered fixed, the hypothesis accepted $\mathrm{Ha}$ and rejected $\mathrm{Ho}$. For variable of compost fertilizer $\left(X_{2}\right), t_{\text {find }}=-0,133$, while $t$ table $(\alpha=0,05)=2,44$. Then $t_{\text {find }}>t$ table which means the null hypothesis is accepted and the alternative hypothesis is rejected at $95 \%$ level.

Any addition of NPK fertilizer $\left(X_{3}\right)$ of $1 \mathrm{Kg}$ will result increased production of $0.750 \mathrm{Kg} /$ $\mathrm{Ha}$ if the production factors $\left(\mathrm{X}_{1}, \mathrm{X}_{2}, \mathrm{X}_{4}, \mathrm{X}_{5}\right.$, and $\left.\mathrm{X}_{6}\right)$ are considered fixed, the hypothesis accepted $\mathrm{Ha}$ and rejected Ho. For the NPK fertilizer variable $\left(X_{3}\right)$ obtained $t$ find $=-2,800$, whereas $t_{\text {table }}(\alpha=0,05)=2,44$. Then $t_{\text {find }}>t_{\text {table }}$ which means the null hypothesis is rejected and the alternative hypothesis is accepted at $95 \%$ level.

Any addition of Urea fertilizer $\left(X_{4}\right)$ of $1 \mathrm{Kg}$ will result in increased production of $2,924 \mathrm{Kg}$ / $\mathrm{Ha}$ if the production factors $\left(\mathrm{X}_{1}, \mathrm{X}_{2}, \mathrm{X}_{3}, \mathrm{X}_{5}\right.$, and $\left.\mathrm{X}_{6}\right)$ are considered fixed, the hypothesis accepted $\mathrm{Ha}$ and reject $\mathrm{Ho}$. For the Urea fertilizer variable $\left(X_{4}\right)$ obtained $t_{\text {find }}=6,609$, while whereas $t_{\text {table }}(\alpha=0,05)=2,44$. Then $t_{\text {find }}>t_{\text {table }}$ which means the null hypothesis is rejected and the alternative hypothesis is accepted at $95 \%$ level.

Any addition of pesticide $\left(X_{5}\right)$ of $100 \mathrm{ml}$ will result increased production of $1,106 \mathrm{Kg} / \mathrm{Ha}$ if the production factors $\left(X_{1}, X_{2}, X_{3}, X_{4}\right.$, and $\left.X_{6}\right)$ are considered fixed, the hypothesis accepted $\mathrm{Ha}$ and reject $\mathrm{Ho}$. For the pesticide variable $\left(X_{5}\right)$ obtained $t_{\text {find }}=4,119$, while $t_{\text {table }} \alpha$ $=0,05)=2,44$. Then $t_{\text {find }}>t$ table which means the null hypothesis is rejected and the alternative hypothesis is accepted at $95 \%$ level.

Any additional labor $\left(X_{6}\right)$ of $1 \mathrm{HKP}$ will result in a production increase of $1,652 \mathrm{Kg} / \mathrm{Ha}$ if the production factors $\left(\mathrm{X}_{1}, \mathrm{X}_{2}, \mathrm{X}_{3}, \mathrm{X}_{4}\right.$, and $\left.\mathrm{X}_{5}\right)$ are considered fixed, the hypothesis accepted $\mathrm{Ha}$ and rejected Ho. For the labor variable $\left(X_{6}\right)$ obtained $t$ find $=5,453$, while $t$ table $(\alpha=0,05)=$ 2,44 . Then $t_{\text {find }}>t$ table which means the null hypothesis is rejected and the alternative hypothesis is accepted at $95 \%$ level.

The simultaneous test results obtained by $F$ test obtained $F_{\text {find }}$ of 172,650 and $F_{\text {table }}(0,01)$ on the confidence level of 95 percent of 2.88 with other words $F_{\text {find }}>F_{\text {table, }}$, this means seed $\left(X_{1}\right)$, compost $\left(X_{2}\right)$, NPK fertilizer $\left(X_{3}\right)$, Urea fertilizer $\left(X_{4}\right)$, Pesticide $\left(X_{5}\right)$ and Labor $\left(X_{6}\right)$ have a very significant effect on rice production.

Furthermore, to see the relation of efficiency of production factor $(Y)$ with seed $\left(X_{1}\right)$, compost fertilizer $\left(X_{2}\right)$, NPK fertilizer $\left(X_{3}\right)$, Urea fertilizer $\left(X_{4}\right)$, Pesticide $\left(X_{5}\right)$ and Labor $\left(X_{6}\right)$ is used determination coefficient $\left(R^{2}\right)$. The results show that $R^{2}=867$, it means that 86.70 percent of the $Y$ variable can be explained by the $X_{1}, X_{2}, X_{3}, X_{4}, X_{5}$, and $X_{6}$ variables, while the other 13.30 percent is explained by other factors out the research.

Table 2 - Efficiency Analysis

\begin{tabular}{|c|c|c|c|c|c|c|c|}
\hline $\begin{array}{l}\text { Production } \\
\text { Factor }\end{array}$ & $\begin{array}{l}\text { Regression } \\
\text { Coefficient } \\
\text { (a) }\end{array}$ & $\begin{array}{l}\text { Average } \\
\text { Production } \\
(\mathrm{Y}) \\
\text { (Kg/Farmers) }\end{array}$ & $\begin{array}{l}\text { Production } \\
\text { Price, } \mathrm{P}_{\mathrm{y}} \\
(\mathrm{Rp} / \mathrm{Kg})\end{array}$ & $\begin{array}{l}\text { Production } \\
\text { Factor } \\
\text { Average (X) } \\
\text { (Sat/Petani) }\end{array}$ & $\begin{array}{l}\text { Production } \\
\text { Factor } \\
\text { Price, } \\
\mathrm{P}_{\mathrm{x}} \\
(\mathrm{Rp} / \mathrm{Kg}) \\
\end{array}$ & $\begin{array}{l}\text { Efficiency } \\
\text { Ratio } \\
\left(\mathrm{aYP}_{\mathrm{y}} / \mathrm{XP}_{\mathrm{x}}\right)\end{array}$ & Information \\
\hline Seed & $-0,09780$ & 4.621 & 4.500 & 62,41 & 5.500 & $-5,92$ & No \\
\hline Compost & $-0,00771$ & 4.621 & 4.500 & 775,69 & 500 & $-0,41$ & No \\
\hline NPK & $-0,28768$ & 4.621 & 4.500 & 139,36 & 2.500 & $-17,17$ & No \\
\hline Urea & 1,07261 & 4.621 & 4.500 & 168,51 & 2.000 & 66,18 & Not yet \\
\hline Pesticide & 0,10140 & 4.621 & 4.500 & 698,40 & 500 & 6,04 & Not yet \\
\hline Labor & 0,50223 & 4.621 & 4.500 & 118,56 & 35.000 & 2,52 & Note yet \\
\hline
\end{tabular}

The ratio between the Marginal Product Value (NPM) of the seed production inpud and the price $\left(P_{x}\right)$ of seed purchase is greater than one $(-5.92)$. It shows that economically the allocation of seed input at the level of $62.41 \mathrm{Kg}$ was inefficient. 
The ratio between the Marginal Product Value (NPM) of the compost fertilizerinput $\left(\mathrm{X}_{2}\right)$ with the compost fertilizer price per kilogram is less than one $(-0.41)$. It shows that economically the allocation of composted fertilizer production input at the level of 775,69 kilogram per Ha was inefficient.

The ratio between the Marginal Product Value (NPM) from the production input of NPK fertilizer $\left(X_{3}\right)$ and the fertilizer price per kilogram is greater than one $(-17.17)$. It shows that economically the allocation of NPK fertilizer production input at the level of 168.51 kilograms per farm was inefficient.

The ratio between the Marginal Product Value (NPM) of the Urea fertilizer production input $\left(\mathrm{X}_{4}\right)$ with the Urea fertilizer price per kilogram is greater than one (66.18). It shows that economically the allocation of urea fertilizer input at the level of 143.83 kilograms per Ha was inefficient yet.

The ratio between the Marginal Product Value (NPM) of Pesticide Production input $\left(X_{5}\right)$ at the pesticide price per milligram is less than one (6.04). It shows that economically allocation from pesticide production input at level $698,40 \mathrm{ml}$ per $\mathrm{Ha}$ that pesticide production factor $\left(\mathrm{X}_{5}\right)$ was inefficient yet.

The ratio between the Marginal Product Value (NPM) of the labor production input to the labor price per HKP is greater than one (2.52). It shows that economically the allocation of labor input at the level of $118.56 \mathrm{HKP}$ thus the labor production factor $\left(\mathrm{X}_{6}\right)$ was inefficient yet.

The amount of farm income earned by rice farmers reached Rp.18.280.533 per Ha, which the amount of dried grain production reached $5.389 \mathrm{~kg}$ per $\mathrm{Ha}$, with the selling price of dried grain Rp.4.500 per $\mathrm{kg}$ and the amount of production value reached $\mathrm{Rp}$ 24.248.258 per $\mathrm{Ha}$. The cost of production reached Rp.5.968.258 per Ha. With an R / C value of 4.063, which means that paddy farming will provide income of 4.063 times from the total cost incurred by farmers.

\section{CONCLUSION}

From Cobb Douglas analysis, it can be concluded that seed production, NPK fertilizer, Urea fertilizer, Pesticide and labor have a significant effected on wetland paddy production, while compost fertilizer production factor has not significant effect on wetland paddy production. Whereas based on the results of the efficiency analysis it was found that the seed factors, compost fertilizer, and NPK fertilizer were inefficient, while Urea, Pesticides and Labor were inefficient yet.

The amount of paddy farming profits earned by the farmers worth, which the benefits are seen from the Reveunue Cost Ratio (R / C) of 4,063.

\section{SUGGESTIONS}

As a suggestions can be given by author which there were several factors of inefficient production of seed factors, compost fertilizer, NPK fertilizer, and labor, so it can be said the saprodi used was excessive and the need to reduction it, in addition to the inefficient yet factors consisting of Urea fertilizer and pesticides, so that the amount of the application can be added. The effort to achieve efficiency in rice farming in terms of technical efficiency, price efficiency and economic efficiency of the need for action in the farming obtained from various sources one of them is from extension workers in order to be able to obtain maximum production. And also the participation of farmers in farmer groups which in the farmer group is a forum to exchange information among farmers.

The effort to increase the income is expected that the farmers can make the addition or reduction of production factors in accordance with the efficiency calculation by doing these activities will provide optimal results, in addition the appropriate types used of production facilities will provide the right results as well. 


\section{REFERENCES}

1. Adhiana. 2005. Analisis Efisiensi Ekonomi Usaha Tani Lidah Buaya (Aloe Vera)di Kabupaten Bogor:Pendekatan Stochastic Production Frontier. [Tesis].Bogor (ID): Sekolah Pascasarjana, Institut Pertanian Bogor.

2. Agustina Pasaribu, Djaimi Bakce, Novia Dewi (2016). Analisis Efisiensi Produksi Usahatani Kelapa di Kecamatan Keritang Kabupaten Indragiri Hilir. Jurnal Online Mahasiswa (JOM) Bidang Pertanian Vol 3, No 1:1-11, Februari 2016.

3. Andi Yulyani Fadwiwati, Sri Hartoyo, Sri Utami Kuncoro, dan I Wayan Rusastra. 2013. Analisis Efisiensi Teknis, Efisiensi Alokatif, Dan Efisiensi Ekonomi Usahatani Jagung Berdasarkan Varietas Di Provinsi Gorontalo. Jurnal Agro Ekonomi. Volume 32 No. 1, Mei 2014: 1-12.

4. Angelia Leovita. 2015. Analisis Efesiensi Usahatani Ubi Jalar di Kecamatan Ampek Angkek Kabupaten Agam Sumatera Barat.(Tesis)Sekolah Pascasarjana Institut Pertanian Bogor.

5. Anjur erik hermade saragih. 2014. Analisis efisiensi produksi usahatani Perkebunan Kelapa Sawit Swadaya (Studi Kasus Pada Perkebunan Kelapa Sawit Swadaya Di Perbatasan Desa Dayo Dengan Desa Tapung Jaya, Kecamatan Tapung, Kabupaten Rokan Hulu). Jurnal Fakultas Pertanian Universitas Riau.

6. Arifuddin Lamusa. 2009. Analisis Efisiensi Teknis Alokasi Input Usaha Tani Padi Sawah Di Daerah Impenso Wilayah Taman Nasional Lore Lindu (TNLL) Provinsi Sulawesi Tengah.J. Agroland 16 (3): 251 - 257, September 2009.

7. Badan Pusat Statistik Kabupaten Aceh Barat. 2015 Aceh Barat dalam angka.

8. Damel Fink Lybaws. 2017. Analisis Efisiensi Ekonomi Penggunaan Faktor-Faktor Produksi Pada Usahatani Padi Ladang Di Kecamatan Pauh Kabupaten Sarolangun. Jurusan Agribisnis Program Studi Agribisnis Fakultas Pertanian Unja.Jurnal Agro Ekonomi. Volume 32 No. 1, Mei 2014: 1-12.

9. Darwanto. 2010. Analisis Efisiensi Usahatani Padi Di Jawa Tengah (Penerapan Analisis Frontier). Jurnal Organisasi dan Manajemen, Volume 6, Nomor 1, Maret 2010, 46-57.

10. Dewi, I.G.A.C. 2012. Analisis efisiensi usahatani padi sawah studi kasus di Subak Pacung Babakan, Kecamatan Mengwi, Kabupaten Bandung. Jurnal Agribisnis dan Agrowisata 1 (1): 1-10.

11. Downey, D. dan Erikson, S., 1992. Manajemen Agribisnis. Penerbit Erlangga. Jakarta

12. Hamdan, 2012.Analisis Efesiensi Faktor Produksi pada Usahatani Padi Sawah di Bengkulu. Jurnal Balai pengkajian Teknologi Pertanian Bengkulu. 